\title{
INSPECTING THE PROFESSION OF GOVERNMENT ACCOUNTANTS IN THE FUTURE
}

\author{
Puji Wibowo $^{1 *}$ and Amrie Firmansyah ${ }^{2}$ \\ ${ }^{1,2}$ Sekolah Tinggi Akuntansi Negara (STAN), Indonesia
}

\begin{abstract}
The accountant has become one of the most prestigious professions around the world since a few decades ago. Research concerning accountant professions has simultaneously been famous and even abundant since then. A number of existing studies discussed these fabulous professions, namely public accountant and chartered accountant, from college students' point of views. This research offers a new perspective with respect to the type of professions and group of respondents. By undertaking questionnaire survey and interviews with government officers as selected respondents, this study tries to reveal the public officers' perceptions, instead of students, towards accountancy professions in the line ministries and government agencies. The questionnaires were distributed to government employees whose jobs are related to public finance management amounted to 300 questionnaires in total. 104 questionnaires were successfully returned, and from those 97 are valid. This preliminary study focuses on government officers' attitude because this topic has been unusual. The study becomes more challenging since it also discusses the impact of Ministry of Finance Decree No. 25 of 2014 concerning State Chartered Accountant on the willingness of government officers to choose professional accountant in public sector as an option to pursue their career. We find that respondents agree with the obligation of re-register of chartered accountant and the role of Indonesian Accountant Association in the process of registration. However, respondents who have already been registered in National Chartered Accountants were not sure whether they would be able to undertake continuous learning program until the retirement ages. This study also discloses that most respondents tend to say that in upcoming years, government accountants have more important roles in audit, taxation, education, local government finance, national budget, cost of public services, and non-tax revenue. Finally, this research proposes policy recommendation that government should take professional accountants into account in arranging career path for public officers.
\end{abstract}

Keywords: chartered accountant, government officers

\section{INTRODUCTION}

Currently, the accounting profession has become one of the most demanding career challenges. The accounting profession services are not only needed by top business actors but also begin to be needed by small and medium entrepreneurs. The essence of accounting presence is even an absolute requirement for business entities that intend to attract the interest of potential investors and creditors. According to Soeherman (2011), the current business world relies heavily on accounting as an information-generating mechanism. Accounting urgency as a profession has even penetrated the geographic boundaries and transformed into one of the global professions (Irmawan, 2010).

* Corresponding author. Email address: puji.wibowo@pknstan.ac.id 
As quoted by Sumaryono and Sukanti (2016), the Indonesian Institute of Accountants (IAI) reported that the number of professional accountants needs in Indonesia has not met the demand. The number of professional accountants for 2015 only amounted to 53,500 people, whereas the needs of accountants at that time reached 425,000 people (www.kompas.com). In addition, there are 226,780 entities that require an unqualified financial statement opinion (IAI, 2014). Institute of Indonesia Accountants reported that the number of certified professional accountants (Chartered Accountant) as members of the Institutes only as many as 15,940 people. This number is unbalanced compared to other ASEAN countries. Malaysia has 30,236 accountants, Philippines 19,573 accountants, Singapore 27,394 accountants, and Thailand 56,125 accountants (IAI, 2014). The relatively small number of Chartered Accountants (CAs) in Indonesia compared to ASEAN countries is worried to be a threat to CA in Indonesia. Based on the Mutual Recognition Arrangements (MRA) signed by ASEAN countries, there are eight professions that are recognized and needed during free trade, namely profession in accounting (IAI 2014 in Sumaryono and Sukanti 2016).

It can not be denied that the accounting profession is not only needed by the private sector but is also demanded by the government sector. Since the state financial reforms marked by the launch of the package of laws of state finance through Act No. 17 of 2003 concerning State Finance, Act No. 1 of 2004 concerning State Treasury, and Act No. 15 of 2014 concerning Audit of State Financial Management and Accountability, the role of accounting becomes unquestionable in the pursuit of accountability and transparency. Important output in the era of financial management Government-based Act No. 17 of 2003 concerning State Finance is the preparation of mandatory financial statements for each government agencies that receive the allocation of funds either from National Budget or Local Budgets. The financial statements have even left a single entry to a double entry system, which has a spectrum of similarities with commercial accounting. In addition, the fact that there is a necessity of implementing the accrual basis since 2015, no doubt the accounting profession has become a truft card for bureaucrats to improve the quality of government's financial reporting (Sundari, 2010 in Ichsan et al., 2014). It is affirmed that accountant engagement is part of the financial information provider presented in the organization's financial statements. Therefore, the accountant is expected to be directly involved in organizational activities.

The strategic role of accountants in the governance sectors nowadays is to address the need for bureaucracies to oversee and assess financial accountability. Unlike the private sector that may more focus on the interests of shareholders, the government sector has a much more complex dimension. The interest parties that are managed by the Government are all components of the Indonesian people represented by politicians in the legislative council. It is understandable that both good and poor quality of the country's financial management will be affected by the drag of political elites that often deplete their time and energy. The independence and professionalism of the accountant are expected to remain robust to oversee state financial accountability and political intervention (Nordiawan, et al., 2007).

Commonly, accountants in government agencies are recognized as auditors on the Supreme Auditor, in which their duties are to provide annual assessments of the Central Government Financial Statement, the Line Ministries 
or Institutions Financial Report, as well as the Local Government Financial Statements opinions. This qualification of opinion is often a benchmark of the success of the government implementation. In addition to being an auditor of the Supreme Audit Agency, accountants in many government sectors are also encountered in the internal government auditor agency both in the Development Supervisory and Finance Board and the Inspectorate General of State Ministries / Institutions. A lot of accounting professions are also required in a tax audit.

However, on the other hand, the role of management accountants in government agencies is now a debatable issue, namely the need for management accountants as skilled internal business consultants in the designing and implementation of appropriate management accounting techniques and involved in business decision-making processes. This is as revealed by Antony and Govindarajan (1998) in Amerieska (2013). Also explained that accounting practice can be viewed based on two dimensions. The first is organized within the organization, facilitating managerial control, while the latter deals with the transmission of accounting information to the external public and raise the issue of the role of information in a democratic state (Mardiasmo 2002, in Amerieska 2013). Therefore, the role of accountants in the processing of information for the interests of the nation becomes very crucial and cannot be underestimated.

The strategic role played by accountants in governments is not only focused on the preparation of financial accounting information presented in Government Financial Statements but also required at every stage of the National Budget and Local Budgets cycles. It is viewed from the perspective of central government financial accountability, at least one accountant is required in each work unit of budget users. With the estimated number of work unit around 29 thousand spread across central government agencies, it can be imagined how high the gap between the number of current professional accountants with the demand from the government sides. This data does not take into account the work unit in the local governments. It is viewed from the number of local government reporting entities without taking into account the local government work units and the local finance management official, local governments require at least 500 accountants. If it includes village entities that are approximately 75,000 , with the euphoria of village funding from the central government today, the professionalism of government accountants will be more meaningful in providing an atmosphere of accountability for central government financial management.

In the broader perspective of national budget management, the role of accountants is also required in budget allocation (for line ministries and intergovernmental transfers) and revenues estimation such as tax and non-tax revenues. The number of current tax officers is estimated around 30 thousands people, of which 15 percent are tax auditors who in fact require accounting competence. The personnel managing non-tax state revenues for all Line Ministries / Agencies is estimated to reach five thousands. Of this number, it is not yet known exactly the number of accountants who are involved in the process of non-tax revenue management.

Based on these facts, it can be concluded that the Government currently faces a very serious challenge to minimize the deviation between the ideal number of accountant needs and current bureaucratic officers. When the demand for accountant is not fulfilled, the Government through the Ministry of Finance issued the Minister of Finance Decree No. 25 of 2014 on State Register 
of Accountants. The decree is actually intended to provide guidelines for the professional development of accountants while providing benchmarks or standards of competence that must be owned by the accountants. However, some articles in the decree are allegedly potentially a stumbling block for some accountants, especially accountants in government sectors. Article 1 of the decree provides that an accountant is a person who has been registered with the State Register of Accountants held by the Ministry of Finance. In the decree also provides that a person who has claimed as an accountant is allowed to perform work related to accounting and financial reporting. To maintain its competence, the Accountant is required to follow continuing professional education organized by the Institute of Indonesian Accountants, a unit of the Ministry of Finance whose tasks and functions undertake guidance to the Accountant, and/or other parties recognized by the Institute of Indonesian Accountants. The continuous learning program which is followed per year shall be at least 30 Credit Units.(SKP) With the system and pattern of Civil Servants turnovers who have not fully consider the title of the profession and education background, the essence of the need of civil servants to maintain competence in the field of accounting worth questionable.

Based on data from the Center for Financial Professional Development, the Secretariat General Ministry of Finance, the number of Indonesian accountants recorded up to before the enactment of The Minister of Finance Decree No. 25 of 2014 as many as 53,869 people. Of these, for the position as of May 9, 2017, the Center reports as many as 17,890 accountants have reregistered as required in the decree. This means more than 66 percent of accountants do not re-register. Unregistered two-third of Indonesian accountants in Registered National Accountants indicate two things. First, it may be an accountant profession not considered as a prestigious thing to be pursued by some accountants previously registered with the center. Secondly, accountants who are not entitled to a chartered accountant degree have no obligation of competency development through continuing professional education by the Institute of Indonesian Accountants. It could be that most accountants who do not re-register are the accountants who work as civil servants. It is interesting to examine how exactly the civil servant's perceptions of the accounting profession, especially since the enactment of The Minister of Finance Decree No. 25 of 2014.

Research on perceptions of accounting profession have been conducted by many previous researchers. However, most of their researches have been more aimed at students or college graduates majoring in accounting as the target of their respondents. This is as revealed by Sumaryono and Sukanti (2016) and Vidalita (2015) who tried to explore the factors that influence the students to take the CA certification exam. Likewise, Asmoro, Wijayanti, and Suhendro (2016), Hardila (2015), have attempted to find the factors that determine the selection of public accounting careers among students. Special career selection for non-public accountants in the accounting student segment is also discussed in Merdekawati and Sulistyawati (2011). The lack of research related to the behavior and attitude of civil servants to the accounting profession among the government officers becomes the main motivation of this research. Therefore, it is expected that this preliminary study will provide a preliminary figure of the perception of civil servants on the profession of government accountants. 


\section{LITERATURE REVIEW}

The researchers generally argue that accountants are principally professional titles or titles given to a scholar who has completed his education in the faculty of economics majoring in accounting at a university in Indonesia and has graduated from Accounting Profession Education. Jumamik (2007) as quoted by Putra (2017) states that the government accountant is an accountant working at a government agency whose main task is to examine the financial responsibility designated by the organizational units in the government or the accountability of the financial appointed to the government.

Longtime before the accountant euphoria in the last decade, the use of Accountant degree in Indonesia has actually been arranged since the pre-order new era, namely by Act No. 34 of 1954. In the Act which states that the accountant's degree only given to those who have an accountant certificate from a public university. Contemporary understanding of accountants can be found in the Minister of Finance Decree No. 25 of 2014 (amended by Minister of Finance 216 of 2017) which stipulates that the accountant is someone who has been registered in the Minister of Finance list. The accountant referred to in the decree is a professional accountant who holds a chartered accountant (CA). According to Sumaryono and Sukanti (2016), the decree in principle defines $\mathrm{CA}$ as a professional accountant who has an accountant register in accordance with applicable legislation, has experience and/or professional practice in accounting, obey and implement professional standards as well as maintaining competence through continuous learning program.

According to Mardiasmo as quoted by Vidalita (2015) the launch of this CA degree is aimed at qualifying as a Professional Accountant, which is in line with guidelines from the International Federation of Accountants (IFAC) association. CA is awarded to Professional Accountant who fulfills all criteria as an Institute of Indonesia Accountants Member. These criteria include having an accountant register in accordance with applicable legislation, having experience and/or carrying out professional practice in accounting, obeying and implementing Professional Standards, as well as maintaining competence through continuous professional education (PPL). Furthermore, Vidalita (2015) said that with the title CA behind, an accountant will obtain many benefits, such as acknowledgment as a professional accountant in accordance with IFAC guidance, be maintained in accordance with IAI provisions that refer to international standards. In addition, one is also recognized for making significant decisions in areas related to financial reporting for the public good. This CA degree aligns Accountants with international accounting professions such as CPA, ACCA, CIMA, or CMA.

Asmoro et al. (2016) state that careers in accounting are categorized among others public accountants, education accountants, corporate accountants, and government accountants. Career options in the field of accounting are in line with the statement Sumaryono and Sukanti (2016). Particularly government accountants usually consist of public officers with undergraduate education backgrounds in accounting that handle the preparation of financial statements, examinations, or taxation. The importance or essence of a profession for a person, including civil servants, is particularly influenced by the perception of the existence of the profession itself.

The perception is an individual process of choosing, managing, and interpreting a stimulus it receives into an assessment of what is around it. As 
quoted from Schiffman and Kanuk (2010) in Nauli et al. (2013), the perception will encourage a person to intend to do something, including the desire of a person to choose an option of the accounting profession to be taken. Besides perception, motivation also plays a significant role in explaining one's actions. Chan (2012) argues that in choosing a profession is closely related to the theory of motivation is the theory of expectancy. According to Sembiring (2009), as quoted by Chan (2012), the motivation is very important for every individual because the motivation promotes individuals to work hard and enthusiastically achieve optimal results.

The results of research on factors that encourage a person to take the CA certification exam have been numerous. However, the previous studies focusing students in university as their respondents. Sukaryono and Sukanti (2016) conducted a survey of 120 accounting students from the Faculty of Economics, Yogyakarta State University class of 2012 and 2013 in the period of 21-28 September 2015. One of the results suggests that the attitudes in CA have a positive impact on students' intention to take CA certification. This means that the better the students' perception of CA, the more it will encourage students to take the CA certification. Meanwhile, Vidalita (2015) surveyed students' perceptions at three universities: Universitas Brawijaya, Muhamadiyah University of Malang and STIE Malang Kucecwara (ABM). The result shows that the most dominant factor level for students to follow the accounting and CA profession education is self-motivation, career motivation, economic motivation, and final motivation award/prestige. Using a similar theory, Felton et al. (1995), as cited by Suliastini and Prastiwi (2012), examine the relationship between attitudes toward CA and student intentions for a career in CA. The study uses 856 end-class business students demonstrating attitudes toward CA is significantly related to student decisions for a career as a CA.

Theory of Planned Behavior (TPB) is actually a further development of Theory of Reasoned Action (TRA) by Ajzen (Jogiyanto, 2007). TRA explains that the rise of behavior because the individual has an intention or desire to do it (behavioral intention). The behavioral intention will determine one's behavior. TRA proposes that the intention to behave is a function of the attitude and subjective norm (subjective norm) to behavior. Ajzen (2012) as quoted by Sumaryono and Sukanti (2016) explains intention changes over time, in addition, short-term TRA results are more significant than the long-term TRA results. Ajzen (2012) develops the TPB by adding a construct that is not yet in the TRA that is the control of perceived behavioral control. In TPB, the behaviors displayed by individuals arise because of the intention to behave (Ajzen, 2012). Concerning this, Sumaryono and Sukanti (2016) argue that the students' view of a career will shape student attitudes in career choices. If the students see that CA is beneficial to themselves it will shape a positive attitude on it, and vice versa. The small number of CAs in Indonesia compared to the large number of graduates of accounting students and the need for CA may indicate that the accounting student's attitude toward CA tends to be negative.

In the context of professional choice in the government sectors, research that has true nuanced governance has been done by Putra (2017) but still using the students as survey respondents. The respondents of this research are 634 students from 2013 Gajah Mada University, University of Indonesia, University of Riau, Andalas University, University of Sultan Syarif Kasim Riau and the Islamic University of Riau. The results suggest that the influence of market 
motivation, economic motivation, work environment, individual personality, professional training and professional recognition have a significant effect on the career selection of accounting students as government auditors. Based on this research, it can be concluded that the strongest motive for accounting students for a career as government auditor is market motive (availability of job vacancy) while professional recognition (in the form of achievement and selfdevelopment) ranks lowest.

The low number of accountants compared to the needs of government agencies may be due to civil servants view of the accounting profession. Especially in the placement system of employees who do not fully apply the principle of "right man on the right job". An accounting scholar could be placed in a part totally unrelated to the management of state finances. The minister of finance decree No. 25 of 2014 which is amended by Minister of Finance Decree No 216 Year 2017 has actually provided an opportunity and convenience for holders of accountant registers to obtain a CA degree without taking a certification exam. In the transitional provisions of the minister of finance decree No. 216 of 2017, it is stated that the accountant who has been registered in the State Register of Accountants prior to the enactment of the decree shall re-register to the Minister within 3 (three) years since the entry into force of the decree by attaching several documents such as copy of state register of accountants certificate and copy of Institute of Indonesia Accountants membership. Furthermore, it is also stipulated that accountants who do not reregister as above procedure, the state register of accountants charter shall be declared invalid and declared no longer registered in the state register of accountants.

The above provisions are simply interesting to be observed in terms of the clause "... declared invalid and unregistered in the State Register of Accountants", can be interpretated that a person will lose an academic degree "Ak" if not re-register. The desire of accountants, especially those working in the government environment to re-register could be caused by perceptions of the urgency of professional accountant degrees in government agencies. It is possible to enlarge perception related to the minister of finance decree No. 216 of 2017 which regulates either mandatory re-registration requirements and delisted accountants from the state register of accountants.

The perceptions on the urgency of the title "Ak, CA" may also be attributed to a view of the impact of a professional title on graduate with a future career development plan for civil servants. Yulianti (2010) states that career development (such as promotion) is highly expected by every employee. Promotion system also greatly helps employees in analyzing their abilities and interests to be more tailored to the needs of human resources with the growth and development of the organization. Moekijat (1995) in Yulianti (2010), said that in career development should be accepted not merely promotion to a higher position, but career success which is meant an employee progress in work, in the form of satisfaction in entrusted position and get knowledge and skills improved.

In addition, another issue in a career development is the opportunity to do something based on the passion, the opportunity to achieve something valuable, the opportunity to learn new things and opportunities to develop skills capabilities. One of the issues to be explored in this research is how civil servants' expectations of career development in government sectors are related 
to their professional accounting profession. By the issuance of the Act No. 5 of 2014 which regulates the civil servants and followed by some implementing regulations such as Government Regulation No. 11 of 2017 concerning Civil Servant Management, career development opportunities of civil servants in accordance with their competence are widely open. In the light of these issues, the government accountants shall have the role to develop their profession to be able to give its own color and contribution more significantly in the management of state finances.

\section{RESEARCH METHODOLOGY \\ 3.1 Sample Selection}

The number of civil servants of the central government based on data from the State Personnel Board as of June 2016 reached more than 950 thousand employees ( 21 percent of total central and local civil servants). Target respondents in this study are civil servants who have education background bachelor degree who have duties and functions related to the management of state finances. Of the number of 950 thousands of civil servants at the central level, the State Personnel Board on its official website does not disclose details of civil servants by education level. Nationally, civil servants with a background of bachelor degree reached more than 2 million people (46 percent of the total civil servants central and regional). This is one way or another causing the difficulty to get an initial figure of the number of sample employees who will be used as prospective respondents in this study.

This study is a preliminary study to capture the initial perception of civil servants who work in the field of state financial management of the accounting profession in the sector of Government. Questionnaires were distributed to 300 civil servants who worked in the field of state financial management with convenience sampling method. Hartono (2016) states that convenience sampling is a convenient sampling is conducted by selecting the free sample by the researcher.

\subsection{Methods and Techniques of Data Analysis}

This research is descriptive quantitative research using primary data and secondary data. The primary data were obtained from the questionnaire survey to obtain respondent perceptions on two main issues in the research, for example, the respondent's views on some clauses in the minister of finance which concerning registered state accountant and respondent's perception on the accounting profession in government institutions. To deepen the perception of some respondents, interviews are also made to the respondents either registered in the state register of accountants or not. The secondary data, among others, in the form of data on the number of civil servants and accountants obtained respectively from the State Personnel Board, the Center for Financial Professional Development, the Secretariat General Ministry of Finance, and Institute of Indonesia Accountants

Questionnaires were distributed to civil servants who work in the field of state finance management. Data were collected through the Google form addressed to the respondent during the period of April 2017. The questionnaire consists of 3 sections. The first part is a questionnaire filled for all respondents (8 questions), the second part is a questionnaire filled only by respondents who had been registered in the state register of accountants (5 questions) and the third part was a questionnaire filled by respondents who were not registered in 
the state register of accountants ( 2 questions). Measurement of the questionnaire by using the Likert scale from 1 to 5 of "strongly disagree" to "strongly agree".

The final part of the questionnaire asked the opinion of all respondents regarding the type of government accounting profession relevant to the needs of the government at this time. The choices of the types of accounting profession included in the questionnaire consisted of the auditors, tax accountants, educator accountants, budget accountants, state nontax revenue accountants, government service cost accountants, and local financial accountants (including village funds). Respondents may choose more than one type of profession. In addition, an open questionnaire was also provided to reveal the reasons for selecting the type of government accounting profession. Thus, there are a total of 15 closed questions and one open question.

Questions related to the issue of the Minister of Finance regulation concerning Registered State Accountant consisted only of 3 items, namely the requirement of the state register of accountants re-registration, the role of Institute of Indonesia Accountants in the re-registration process and the consequences of losing the title for those who did not re-register. Questions related to the perception of civil servants on the accounting profession of the government include the interests of respondents to work in the field of accounting or interest to work outside the field of accounting, the need for degree requirements for certain positions in government, and views civil servants who re-register state register of accountants on continuous learning program. The questions specifically addressed to respondents who do not have the "Ak, CA" degree is about their interest in the CA certification exam and their motivation to achieve it.

Even though the survey conducted in April 2017, far before the issuance of Minister of Finance Decree No 216 of 2017, the issues arise from the enactment of former regulation (Minister of Finance Decree No 25 of 2014) are still relevant to discuss in this research. Only 3 out of 15 closed questions which were directly dedicated to the substances of Decree Number 25. Furthermore, topics discussed in the former regulation which were questioned in the surveys were still unchanged in the newest regulation. We could say that the cancellation of Minister Decree No 25 of 2014 does not significantly affect our current research.

\section{ANALYSIS OF RESEARCH RESULTS}

This research applies survey by using questioners. The number of respondents who contacted to fill the questionnaires as many as 300 people. The number of respondents who returned the filled questionnaires amounted to 104, while the valid questionnaires of 97. Characteristics of respondents are presented in Table 1 below. 
Table 1 Respondents Profile

\begin{tabular}{|c|l|c|c|r|r|}
\hline \multirow{2}{*}{ No } & \multirow{2}{*}{ Respondent Profiles } & \multicolumn{2}{|c|}{ Registered Accountants } & \multirow{2}{*}{ Number } & \multirow{2}{*}{$\%$} \\
\cline { 3 - 4 } & & Yes & No & & \\
\hline I & By Ages & $\mathbf{3 1}$ & $\mathbf{6 6}$ & $\mathbf{9 7}$ & \\
\hline & 20- 30 years & - & 9 & 9 & 9.3 \\
\hline & $31-40$ years & 14 & 38 & 52 & 53.6 \\
\hline & $41-50$ years & 16 & 18 & 34 & 35.1 \\
\hline & Above 50 years & 1 & 1 & 2 & 2.0 \\
\hline II & By Education Levels & $\mathbf{3 1}$ & $\mathbf{6 6}$ & $\mathbf{9 7}$ & \\
\hline & S1/DIV in Accounting & 31 & 38 & 69 & 71.1 \\
\hline & S1/DIV in Non Accounting & - & 28 & 28 & 28.9 \\
\hline III & By Occupation Positions & $\mathbf{3 1}$ & $\mathbf{6 6}$ & $\mathbf{9 7}$ & \\
\hline & Staffs & 7 & 35 & 42 & 43.3 \\
\hline & Functional Officers & 16 & 13 & 29 & 29.9 \\
\hline & Structural Officers & 8 & 18 & 26 & 26.8 \\
\hline IV & By Offices & $\mathbf{3 1}$ & $\mathbf{6 6}$ & $\mathbf{9 7}$ & \\
\hline & Ministry of Finance-PKN STAN & 6 & 19 & 25 & 25.8 \\
\hline & Ministry of Finance-Non PKN STAN & 25 & 45 & 70 & 72.2 \\
\hline & Non Ministry of Finance & - & 2 & 2 & 2.0 \\
\hline V & By Gender & $\mathbf{3 1}$ & $\mathbf{6 6}$ & $\mathbf{9 7}$ & \\
\hline & Male & 22 & 52 & 74 & 76.3 \\
\hline & Female & 9 & 14 & 23 & 23.7 \\
\hline
\end{tabular}

Source: Processed

Based on Table 1 above, it can be concluded that the respondents who have filled out the questionnaire consisted of 74 male civil servants $(76.3 \%)$ and 23 female civil servants (23.7\%). Judging from the age composition, most respondents were from age group 31 up to. 40 years (53.6\%), followed by the age group 41 up to 50 years (35\%). Age group 31 up to 50 years is a productive period for civil servants because it is still far from the retirement age of civil servants (58 years). That is, in the age range, civil servants still have many opportunities to choose the desired career path. Respondents with such age compositions are expected to reflect a reasonable perception of a bureaucrat. If we look at the educational background, respondents in this study have largely completed a bachelor degree in accounting $(71.1 \%)$. This condition reflects that most respondents are relatively more concern about the profession of government accountants. Based on the position of personnel, the respondents are dominated by civil servants with the position of an executor/staffs who reached more than 40 percent. It can be seen at the origin of the respondent institutions, most of them come from the Ministry of Finance. Although the majority of respondents are educational background in accounting, the respondents who have been recorded in the state register of accountants (have degree Ak, CA) only 31 employees (31.9\%). This means that most civil servants from accounting scholars do not become members of the Institute of Indonesia Accountants. 
Table 2 Part I : Validity Test Results

\begin{tabular}{|c|c|c|c|c|c|c|}
\hline Statements & $\mathbf{N}$ & Minimum & Maximum & Mean & Std. Deviation & Remarks \\
\hline 1 & 97 & 1.00 & 5.00 & 3.6837 & .84459 & Valid \\
\hline 2 & 97 & 1.00 & 5.00 & 3.4898 & .93329 & Valid \\
\hline 3 & 97 & 1.00 & 5.00 & 3.0000 & 1.29232 & Valid \\
\hline 4 & 97 & 1.00 & 5.00 & 3.7143 & .95248 & Valid \\
\hline 5 & 97 & 1.00 & 5.00 & 2.3299 & .95439 & Not Valid \\
\hline 6 & 97 & 1.00 & 5.00 & 3.4082 & .91760 & Valid \\
\hline 7 & 97 & 1.00 & 5.00 & 3.6735 & 1.04315 & Valid \\
\hline 8 & 97 & 1.00 & 5.00 & 2.3980 & .90519 & Valid \\
\hline
\end{tabular}

Table 2 shows that based on the results of the validity test of the item statement part I, seven out of eight questions declared valid. Therefore most questionnaire questions in section I have been valid questions to be submitted to respondents. The only invalid question is for statement number 5 ('I am not interested in work outside the accounting field') because $r$ arithmetic $(0.197)$ is lower than $r$ table (0.1986), so it cannot be used for test reliability. For reliability test, it is known that the seven items of the statement have Cronbach alpha 0.457 (according to Hair and Black, 2014) fall into the category quite reliably, so the seven items can still be used in this study. The results of validity test on the seven questions include 1 . Respondents stated that the obligation to re-register for Accountants set out in the minister of finance decree No. 25 of 2014 is quite appropriate. This is evident from the average respondent's answer of 3.6837.

Respondents stated that the role of Institute of Indonesia Accountants in the re-registering of Accountants is quite appropriate. This is evident from the average respondent's answer of 3.4898. Some respondents mentioned that Accountants who do not do re-register any longer entitled to the title of Accountant and some states are entitled. This is evident from the average respondent's answer of 3,000. Respondents are actually interested in working in the field of accounting. This is evident from the respondent's answer of 3.7143. Even from the seven-item statements, these items have the highest average. Respondents stated that accountants in the government sector tend to work in the field of accounting. This is evident from the respondent's answer of 3.4082. Respondents tend to agree that the accounting profession title in the government sector needs to be required to occupy a certain position or function. This is evident from the respondent's answer of 3.6735. Respondents tend to state that jobs related to government sector accounting are not limited to the preparation, analysis, and audit of financial statements. This is evident from respondent answers of 2.3980. From the results of respondents' answers to the questionnaire part, I shows that the accountant and accountant profession is still considered important by most respondents. The accountant's degree is still considered prestigious, so the obligation to register the state accountant for the owner of the accountant degree must be done in accordance with the provisions in the PMK. Respondents expect that holders of accountant degrees in the Government sector are more likely to work in the field of accounting, but not just on the preparation, analysis, and examination of financial statements. Respondents still consider that non-accounting job in the Government sector requires the participation of accountants. 
Furthermore, the questions in part II only filled by respondents who have been registered in the state registration accountant, that is as many as 31 people. Validity test is performed on all five items of the statement in the questionnaire of each part II. Table 3 below shows that the five questions are valid because $r$ counts more than $r$ table $(0.355)$.

Table 3 Part II : Validity Test Results Hasil Uji Validitas Pernyataan Kuesioner

\begin{tabular}{ccccccl}
\hline Statements & N & Minimum Maximum & Mean & Std. Deviation & Remarks \\
\hline 9 & 31 & 1.00 & 5.00 & 4.0645 & .77182 & Valid \\
10 & 31 & 1.00 & 4.00 & 2.5161 & 1.02862 & Valid \\
11 & 31 & 1.00 & 5.00 & 3.0968 & 1.01176 & Valid \\
12 & 31 & 1.00 & 4.00 & 2.5806 & 1.05749 & Valid \\
13 & 31 & 1.00 & 5.00 & 2.8710 & 1.14723 & Valid \\
\hline
\end{tabular}

From table 3 above, it shows that based on the results of the validity test of item statement part II, all statements are valid. Furthermore, the reliability test, indicating that the five statement items have Cronbach alpha 0.672 entered in the reliable category (Hair and Black, 2014), so the five items can still be used in this study. Respondents tend to agree that the competence of Accountants needs to be maintained at a considerable level through continuous learning program. This is evident from the average respondent's answer of 4.0645. Respondents tend to have difficulty in meeting the minimum requirements of continuous learning program credits. This is evident from the average respondent's answer of 2.5161. Respondents tend to agree to meet the minimum credits requirements for many years up to retirement ages. This is evident from the average respondent's answer of 3,0968. Respondents tend to disagree on administrative sanctions if the respondent cannot meet the minimum credit requirements. This is evident from the average respondent answer of 2.5806. Respondents who are all accountants in the government sector are not interested in working outside the governmental sector just to take the title of Ak. This is evident from the average respondent's answer of 2.8710. Under such conditions, civil servants with an Ak degree are not interested in moving to just defend the title of Ak. The authors suspect that the title Ak is not a guarantee for accountants, especially those working in the Government sector to get better jobs outside the sector of Government. Likewise, the remuneration system in the Ministry of Finance is likely much more attractive than others.

From the results of the questionnaire in section II above shows that an accountant must update his / her knowledge through continuing education program. The existence of the development of knowledge and information in the field of accounting requires the accountants must always develop their skills in the field of accounting in accordance with the development of the era. However, the obligation to maintain an accountant degree by fulfilling SKP is quite difficult for civil servants who already have a degree Ak. This is allegedly related to the problem of time to fulfill credits conducted during working hours such as training programs conducted by Institute of Indonesia Accountants, seminars, and workshops in the field of accounting, call for papers, and so forth. The condition resulted in the limitations of civil servants who have an accounting degree to fulfill it, unless it can be done in the presence of agency 
leaders' instructions by issuing a letter of assignment or agency support through fees for the fulfillment of the credits, so with such conditions, they disagree if given sanctions due to unable to meet the target fulfillment of credits. Thus, it can reduce the reluctance or difficulty of civil servants who have an accounting degree to comply with the credit norms because basically, they assume that credits are not only to fulfill its obligation as an "Ak" holder but also to improve their competence and knowledge in the accounting field. Furthermore, government officers who have a degree accountant assume that employment as a civil servant is the ideal job for them. It is alleged that the real sector of government is very attractive to accountants related to their role in maintaining accountability and transparency in the field of state finances that have an impact on information to the public.

From the interviews results with some respondents who retained the title Ak, obtained various answers. For some respondents who work as lecturers, the title of $\mathrm{Ak}, \mathrm{CA}$ is considered prestigious because they have to deal with colleagues fellow lecturers more frequently in forums seminars, call for papers, or meetings. Some argue that prestigious is not the main problem, but rather 'feel saying' if you have to lose the degree of accountant obtained when taking accounting and accounting undergraduate education.

For the third part of the questionnaire, the statements are addressed to respondents who are not registered in the RNA (66 people). The result of validity test for all items of questionnaire question part 3 is presented in table 4 below. From the table, it is seen that a couple of questions are valid because they have higher $\mathrm{R}$ count than $\mathrm{r}$ table (0.2404).

Tabel 4 Part III: Validity Test Results

\begin{tabular}{ccccccc}
\hline Statements & N & \multicolumn{2}{c}{ Minimum } & Maximum & Mean & \multicolumn{2}{c}{ Std. Deviation Remarks } \\
\hline 14 & 66 & 1.00 & 5.00 & 3.1970 & 1.15319 & Valid \\
15 & 66 & 1.00 & 5.00 & 2.7727 & 1.16084 & Valid \\
\hline
\end{tabular}

For reliability testing yields Cronbach alpha 0.493 (according to Hair and Black., 2014) fall into the category quite reliably, so the seven items can still be used in this study. Respondents who do not have a degree Ak tend to have an interest for professionally certified accountant examinations for an Ak. This is evident from the average respondent's answer of 3.1970. We suspect that civil servants who do not have an Ak degree, the accounting profession is a pretty interesting profession. However, the respondents are still not paying attention the obligation of the accounting profession to maintain its competence level, among others through continuing professional education every year. The absence of information about the cost of certified professional accountant examinations is also relatively expensive suspected to be one cause.

In obtaining the title of an accountant, the motivation of respondents is not encouraged to the interest to be able to work outside the government sector. This is evident from the average respondent answer of 2.7727. It is possible that respondents who have an interest in taking an accounting certification exam are more likely to remain in the government sector than for a private sector career. Another thing is the respondents may have the view that the accountant degree is limited to adding a degree only without understanding the consequences that must be done by respondents such as maintaining competence through continuous learning program as explained above. 
Interviews were also conducted with some respondents who were not registered in the state register of accountants. A respondent who already has a Chartered Public Accountant (CPA) degree argues that a CA degree has no meaning to him. "For what?" If I get a CA degree, I have to follow the PPL, it's expensive! ", one of our respondents said. Another case with other respondents who have a bachelor degree in accounting. When asked if he or she is interested in taking a professional accounting certification exam? The answer, "interested for sure, I just want to know, what accountant look like".

At the end of the questionnaire, prospective types of future government profession in are provided to choose. The answer to the question for each respondent can be more than one choice. The auditor profession and tax accountant are the most favored professions by the respondents because both are selected by 75 respondents. The result is not surprising considering the two professions are government accounting careers that have been widely known by public officers. The accountant profession that is considered urgent in the future is the financial accountant of the region in which there is also the management of village funds. This profession was chosen by 73 respondents. The high choice of regional financial accounting profession may be due to the fiscal decentralization euphoria that has been echoed in the country since the beginning of the millennium. This condition is reinforced by the existence of the village fund policy that was introduced since the enactment of the Village Act of 2014. Therefore, the authors consider the reasonable choice of respondents.

The following accounting profession choices are the accountant of educators (63 respondents), accountants in the cost of government services needed to calculate the cost standard for the Ministry / Institution budget (55 respondents), an accountant in the budget (54 respondents), and the last accountant field of Non-Tax State Revenue of 48 respondents. Non-Tax State Revenue ranks are the lowest in the choice of profession can be caused by two things. First, most respondents $(97.79 \%)$ come from the Ministry of Finance which is generally more familiar with the term taxation compared with the NonTax State Revenues. Some of the respondents of this study also came from the Directorate General of Taxes and lecturers who teach the subject of taxation. The second cause, the accounting profession in the field of the Non-Tax State Revenue accountants not so widely known by the public. Moreover, the lack of respondents from the Ministry / Institution also contributed to the low choice of respondents. If the research increases the number of respondents from the Ministry / Institution, which is largely a Non-Tax State Revenue management institution, it may be that the choice of the profession of the Non-Tax State Revenue accountants can be boosted up.

From the reasons presented by the respondents, it appears that in general respondents view all types of accounting profession contained in the questionnaire is important in the management of state finances. The choice of the auditor profession and the tax accountant is more due to the view that the Government is currently intensively raising tax revenues, among others through the expansion of tax base and tax extensification.

\section{CONCLUSIONS, IMPLICATIONS, AND LIMITATIONS OF RESEARCH}

This research is principally a preliminary study in order to obtain a preliminary picture of the perception of government officers on the 


\section{INSPECTING THE PROFESSION OF GOVERNMENT ACCOUNTANTS IN THE FUTURE}

development of the government accounting profession. Previous research on the views of the accounting profession is more about the perception problem among the students towards the public accountant profession or above to take the certification examination of professional accountants. Our research also contributes to the renewal of respondents who are no longer from students, but ASNs, perceptions of the accounting profession focused on government accountants, and perceptions of Minister of Finance Decree No 25 of 2014 which are currently being discussed by academics and practitioners.

The two main issues raised in this study include the views of civil servants on the implementation of the Decree and the perception of bureaucrats to the profession of government accountants. Based on a questionnaire survey of 97 respondents and interviews on selected respondents, it can be concluded as follows.

a. Respondents tend to agree with the provisions set out in the Decree No. 25 of 2014, in particular regarding the obligation to re-register and the role of Institute of Indonesia Accountants in the process of re-registration of RNA. As for the provisions on the consequences of non-registration of RNA registers, some respondents agreed, but others did not agree with the provisions in question. Even the Decree No 25 of 2014 has been canceled by current regulation, the Decree No 216 of 2017, the issues are still relevant because existing regulation formulates the same process business as the former regulation.

b. Respondents tend to agree that accountants in government agencies should work in accounting. There is even a tendency that for a certain position should be required degree accountant.

c. Respondents who have been enrolled in the RNA tend to agree on current provisions and will even try to follow the continuous learning program until after service. However, the respondents also claimed to have difficulties to continue to meet these requirements.

d. Respondents who have not been enrolled in the RNA tend to have an interest in taking certified professional accounting exams while still working in government agencies.

e. Respondents generally agree that accountants are demanded in every aspect of government financial management, while still favoring tax accountants and auditors as prospective professional choices.

The results of this study provide a signal for government officers regarding career options in accounting. With the increasing complexity of state financial management problems in upcoming years, the accounting profession in government is considered very urgent. All aspects of financial management of the country either from the side of planning (budgeting) or the stage of accountability (reporting) require the role of professional accountants. The existence of mandatory continuous learning program for accountants is quite burdensome. However, if the field of duties and functions of government employees directly related to the accounting, we believe that the head of government agencies will provide full support for the development of competence in the field of accounting.

For policymakers, there is at least a couple of policy implications to consider. First, the need to evaluate the implementation of the minister of Decree No. 216 of 2017 to identify real issues in the field. At least the number 
of accountants who do re-register state register of accountants was alleged because the decree was deemed unable to provide a cool atmosphere for the accountants. Second, the government needs to reconsider the policy of mutation patterns and career paths in their respective offices. With the issuance of Government Regulation No. 11 of 2017 concerning the Management of Civil Servants, it is expected that the government would be more open in arranging the pattern of civil servant mutation to suit their competence. A view of the need for professional accountant degree requirements to occupy a particular post is an idea worth examining in depth. Currently, there are many positions of state financial managers that are not held by accountants. Placing accountants in several strategic positions to support state financial management is not a difficult choice. With the number of central and regional public officers with a background of bachelor degree reaching 2 million employees, accounting career development options are well worth considering, including accountants in village financial management.

For further research, this study can be developed in the field of behavioral accounting by using both quantitative and qualitative methods. Key points that can be further developed in subsequent research. First, the sample size of respondents need to be reproduced, among others, by increasing the number of respondents from the line ministries/agencies. Second, further research is expected to reach local government officers of more than 3 million people with an adequate sample of respondents. Third, this research has not analyzed deeply about the motives of each respondent to maintain the title of Ak or who is not too concern with the professional accountant's degree. The last but not least, it needs for an in-depth interview and focuses group discussion especially to know the opinion of policymakers about the possibility of professional development of government accountant.

\section{References}

Amerieska, S. (2013). Etika Akuntan Manajemen Pemerintahan Daerah dalam Penyusunan Anggaran Publik Guna Mencapai Good Local Governance (framework: Teori Keagenan).Paper. Politeknik Negeri Malang.

Asmoro, T. K. W., Wijayanti, A., \& Suhendro. (2016). Faktor-Faktor Yang Mempengaruhi Mahasiswa Akuntansi Dalam Pemilihan Karir Sebagai Akuntan Publik. JEAM, Vol XV April 2016: 68-79.

Chan, A. S. (2012). Analisis Faktor-Faktor Yang Mempengaruhi Pemilihan Karir Menjadi Akuntan Publik Oleh Mahasiswa Jurusan Akuntansi. Jurnal Ilmiah Mahasiswa Akuntansi - Vol 1, No. 1, Januari 2012: 5358.

Hair, J., \& Black, W. C. (2014). Multivariate Data Analysis: Pearson International Edition. The University of Twente.

Hartono, J. (2016). Metodologi Penelitian Bisnis: Salah Kaprah dan Pengalaman-Pengalaman. Yogyakarta: BPFE.

Ichsan, T., Nugroho, H., \& PS, Y. F. (2014). Peran Akuntan Dalam Mewujudkan Good Governance Pada Organisasi Sektor Publik Dan Pengaruhnya Terhadap Kinerja Organisasi. Epigram, 10(2), 64-74. 
Irmawan, Y. (2007). Globalization and Accountancy Profession in Developing Countries. [Dissertation]. UK: University of Bradford.

Merdekawati, D. P., Sulistyawati, A. I. (2011). Faktor-Faktor yang Mempengaruhi Pemilihan Karir Akuntan Publik dan Non Akuntan Publik. Aset, Maret 2011, 9-19.

Nauli, P., Sudrajat, N. D. (2012). Mengapa Semakin Banyak Jumlah Alumni Akuntansi tidak Sebanding dengan Pertumbuhan Kantor Akuntan Publik (Persepsi Mahasiswa Akuntansi terhadap Profesi Akuntan Publik Setelah UU No. 5 Tahun 2011 Tentang Akuntan Publik). Prosiding Seminar Nasional.

Nordiawan, D., Putra, I.S., \& Maulidah, R.. (2007). Akuntansi Pemerintahan. Jakarta: Salemba Empat.

Putra, S.E. (2017). Faktor-Faktor Yang Mempengaruhi Minat Pemilihan Karir Mahasiswa Akuntansi Sebagai Auditor Pemerintah (Studi Empiris Mahasiswa Jurusan Akuntansi Ugm, Ui, Unri, Unand, Uin Suska Dan Uir). JOM Fekon, 4(1), 353-365.

Silvana, H. (2015). Faktor-Faktor Yang Mempengaruhi Mahasiswa Akuntansi Dalam Pemilihan Karir Sebagai Akuntan Publik. [Thesis]. Universitas Andalas.

Soeherman, B. (2011). Tinjauan Kontemplatif Peranan Akuntan di Era Konseptual: Perimbangan Kembali Kehakikian Otak Kiri dan Otak Kanan. Jurnal Akuntansi Multiparadigma (JAMAL), 2(2), 279-293.

Sulistiani, D., \& Prastiwi, A. (2012). Faktor-Faktor Yang Memengaruhi Niat Mahasiswa Akuntansi Untuk Berkarier Sebagai Akuntan Publik: Aplikasi Theory Of Planned Behavior (Studi Empiris Pada Mahasiswa Universitas Diponegoro). Jurnal Skripsi.

Sumaryono, S. (2016). Faktor-Faktor yang Mempengaruhi Niat Mahasiswa Akuntansi Untuk Mengambil Sertifikasi Chartered Accountant. Jurnal Profita, 7, 1-20.

Vidalita, P. A. (2015). Faktor-Faktor yang Mendorong Mahasiswa Mengikuti Prndidikan Profesi Akuntansi Dan Chartered Accountant (Survei Pada Mahasiswa Ppak Di Malang). Jurnal Ilmiah Mahasiswa FEB Universitas Brawijaya, 4(1).

Yulianti. (2010). Pengaruh Motivasi, Pola Kepemimpinan Dan Pengembangan Karir Terhadap Kinerja Karyawan Bidang Keuangan Pada Pemerintah Kabupaten Sukoharjo. [Skripsi]. Surakarta: Universitas Muhammadiyah. 